\title{
Islamic Financial Literacy Amongst Muslim Students in Indonesia: A Multidimensional Approach
}

\author{
Muhammad Raihan Aulia Firdausi ${ }^{1}$, Rahmatina Awaliah Kasri ${ }^{2}$
}

\author{
${ }^{1}$ Fakultas Ekonomi dan Bisnis, Universitas Indonesia, Gedung Soenario Kolopaking, Kampus Widjojo \\ Nitisastro, Jl. Prof. Dr. Sumitro Djojohadikusumo, Kukusan, Kec. Beji, Depok, Jawa Barat 16424, Indonesia, \\ muhammad.raihan78@ui.ac.id \\ ${ }^{2}$ Fakultas Ekonomi dan Bisnis, Universitas Indonesia, Gedung Soenario Kolopaking, Kampus Widjojo \\ Nitisastro, Jl. Prof. Dr. Sumitro Djojohadikusumo, Kukusan, Kec. Beji, Depok, Jawa Barat 16424, Indonesia, \\ rahmatina@ui.ac.id
}

\begin{abstract}
Although Indonesia is the largest Muslim country in the world, the level of Islamic financial literacy in Indonesia is still very low. The Islamic financial literacy index in Indonesia is at $8.93 \%$, much lower than the conventional financial literacy index which reached $37.72 \%$ in 2019 . Therefore, this study aims to analyze the determinants of Islamic financial literacy in Indonesia amongst university students which is a group prioritized by government policies in improving Islamic financial literacy. To achieve this goal, this study develops a multidimensional Islamic financial literacy instrument that includes aspects of knowledge, attitudes and behavior and measures the multidimensional Islamic financial literacy amongst university students. The study collected primary data from 439 students from University of Indonesia and analyzed them using logistic regression method with Islamic financial literacy scores as the dependent variable and socio-demographic factors as the independent variables. The results of this study found that the majority of students $(50.1 \%)$ had moderate levels of Islamic financial literacy, while $43.5 \%$ and $6.4 \%$ had high and low levels of Islamic financial literacy respectively. In addition, this study found a positive influence on the field of study, income, and Islamic bank account ownership on the level of Islamic financial literacy. In particular, students who come from the faculty of economics and business, have higher incomes, and have Islamic bank accounts tend to have higher Islamic financial literacy than other students. Based on these findings, relevant stakeholders in Indonesia are expected to continue improving Islamic financial literacy through various strategies and massive educational programs, especially for the groups which have low and moderate Islamic financial literacy. The results of this study are also expected to enrich the literature on Islamic financial literacy in Muslim countries.
\end{abstract}

Keywords: Financial literacy, Islamic financial literacy, Islamic financial literacy of students, multidimensional Islamic financial literacy.

\begin{abstract}
Abstrak. Walaupun Indonesia merupakan negara Muslim terbesar di dunia, tingkat literasi keuangan syariah di Indonesia masih tergolong sangat rendah. Indeks literasi keuangan syariah di Indonesia berada di angka $8.93 \%$, jauh lebih rendah dibandingkan indeks literasi keuangan konvensional yang mencapai $37.72 \%$ pada tahun 2019. Oleh karena itu, penelitian ini bertujuan untuk menganalisis determinan literasi keuangan syariah di Indonesia pada mahasiswa yang merupakan kelompok prioritas dalam kebijakan pemerintah untuk meningkatkan literasi keuangan syariah. Untuk mencapai tujuan tersebut, penelitian ini mengembangkan instrumen literasi keuangan syariah multidimensi yang mencakup aspek pengetahuan, sikap dan perilaku serta mengukur literasi keuangan syariah multidimensi di kalangan mahasiswa. Penelitian ini mengumpulkan data primer dari 439 mahasiswa Universitas Indonesia dan menganalisisnya menggunakan metode regresi logistik dengan skor literasi keuangan syariah sebagai variabel terikat dan faktor sosiodemografi sebagai variabel bebas. Hasil penelitian ini menemukan bahwa sebagian besar mahasiswa (50.1\%) memiliki tingkat literasi keuangan syariah sedang, sedangkan $43.5 \%$ dan $6.4 \%$ memiliki tingkat literasi keuangan syariah tinggi dan rendah. Selain itu, penelitian ini menemukan adanya pengaruh positif dari bidang studi, pendapatan, dan kepemilikan rekening bank syariah terhadap tingkat literasi keuangan syariah. Secara khusus, mahasiswa yang berasal dari Fakultas Ekonomi dan Bisnis, memiliki pendapatan yang lebih tinggi dan memiliki rekening bank syariah cenderung memiliki literasi keuangan syariah yang lebih tinggi dibandingkan mahasiswa lainnya. Berdasarkan temuan tersebut, pemangku kepentingan terkait di Indonesia diharapkan dapat terus meningkatkan literasi keuangan syariah melalui berbagai strategi dan program edukasi yang masif terutama bagi kelompok mahasiswa dan masyarakat yang memiliki literasi
\end{abstract}


keuangan syariah rendah dan sedang. Hasil penelitian ini juga diharapkan dapat memperkaya literatur terkait literasi keuangan syariah di negara-negara Muslim.

Kata kunci: Literasi keuangan, literasi keuangan syariah, literasi keuangan syariah mahasiswa, literasi keuangan syariah multidimensi.

\section{INTRODUCTION}

\section{Background}

Financial literacy is an individual's essential need to achieve financial well-being (Letkiewicz and Fox, 2014). Financial well-being is the ability to have financial security and have the freedom to make choices now and for the future. Financial literacy is a crucial factor in financial well-being because it gives a person the ability to manage finances in his life (Huston, 2010). Lusardi and Mitcell (2011) show that there is a positive association of financial literacy with one's personal wealth. One's financial literacy will also improve one's ability in financial planning with the knowledge, skills, and attitudes needed to build good financial conditions now and in the future. Financial literacy will make a person able to make decisions on financial matters correctly (Lusardi and Mitchell, 2014). Williams (2007) mentions that in aggregate financial literacy is not only important for personal interests but can reduce the negative impact of the financial crisis in aggregate.

Improvements in financial literacy in Indonesia are expected to support efforts to achieve financial system stability, improve people's welfare, and more inclusive development (OJK, 2017). Currently, the Indonesian Islamic finance industry has developed quite well with an asset value of IDR 1,836.57 trillion in February 2021. Nevertheless, the presence of many Islamic financial institutions has not been matched by the demand side for Islamic financial services products with indications of the level of Islamic financial inclusion in Indonesia which has only reached 9.1 percent. Stakeholders in the Islamic finance industry also need to review the Indonesian Islamic financial literacy index which is at 8.93 percent (OJK, 2019).

This figure shows that Islamic financial literacy is still very low when compared to the level achieved in the conventional financial literacy index which is 37.72 percent. Figure 1 shows a comparison of the increase in conventional and Islamic financial literacy. The increase in Islamic financial literacy has only increased by 0.83 percent for 3 years since the survey was conducted in 2016 . When compared with conventional financial literacy which increased by 8.22 percentage points from 29.5 percent to 37.72 percent, the increase is relatively low (OJK, 2019). This data shows an ironic situation considering that Indonesia is the largest Muslim population in the world. This situation will certainly complicate the development of the Islamic finance industry in the future.

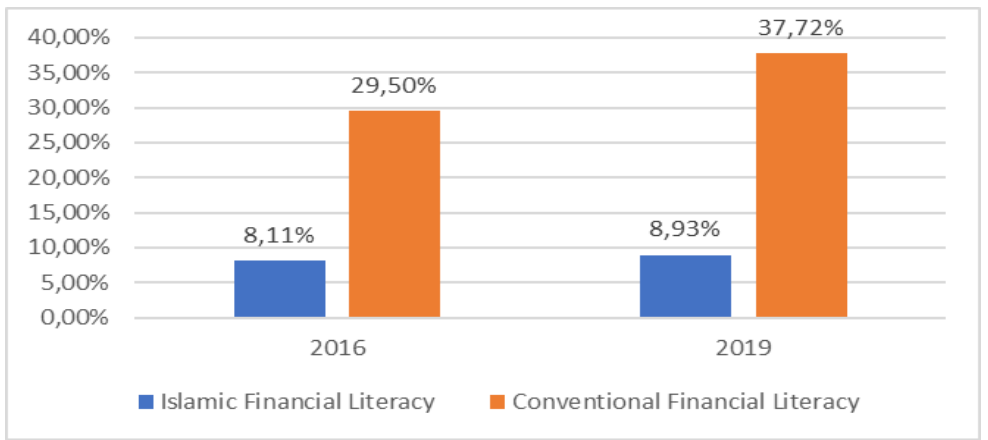

Source: OJK, 2019.

Figure 1 Comparison of conventional financial literacy levels and Islamic financial literacy levels 
The Financial Services Authority has launched various strategies to improve financial literacy in Indonesia through the Indonesian Financial Literacy National Strategy since 2013. The strategy was refined in 2017 to optimize the achievement of the financial literacy and inclusion index targets. This revised Indonesian Financial Literacy National Strategy also focuses on activities to improve financial literacy in certain groups. One of the community groups that is a priority group in the target of this activity is the college student (OJK, 2017). Students are also considered as a crucial community group to have stability in financial literacy because financial literacy has an important role to build financial behavior that will lead to prosperity in the future (Beverly and Burkhalter, 2005). Compared to adults, the student level is a period or phase where a person can be in the development stage for the formation of attitudes and behavior as well as enrichment of knowledge and skills related to finance (Shakirah et al., 2020). Thus, financial literacy will become the main means for today's youth to be able to direct the economy for the better.

In addition, a significant change in the Indonesian Financial Literacy National Strategy (OJK, 2017) revision is the change in the meaning of financial literacy. Changing the notion of financial literacy is to add aspects of financial attitudes and financial behavior in addition to knowledge, skills, and confidence in financial institutions, products, and services to improve the quality of decision making and financial management to achieve prosperity (OJK, 2017). Improvements to the concept of literacy are needed because the concept is a more representative and relevant meaning in describing financial literacy in the community. Chaulagain (2015) reveals that students who approve of saving to save lives in the future do not execute what they know in their attitudes and behavior. The study proves that behavior and attitudes in finance are not always correlated or aligned with understanding or mastery of material from finance. This proves that there is a need to review multidimensional financial literacy which is expected to be a reference for developing financial management that has implications for welfare.

Various studies have been conducted to analyze student financial literacy. Studies that have been conducted prove that in general, gender, study background, and income have a significant effect on financial literacy. Chen and Volpe (1998) study in America, for example, concluded that students with non-business majors, women, students with lower GPA, age under 30, and little work experience generally have lower levels of financial literacy. A similar study was conducted by Beal \& Delpachitra (2003) in Australia and found that students undertaking business studies, even they were in their first year at university, had higher financial literacy. A study of financial literacy has also been conducted in Indonesia by Lantara and Kartini (2015) at Gajah Mada University. This study took a sample of undergraduate and postgraduate students at Gajah Mada University and found that male students, from the Faculty of Economics and Business, high income, long-standing work experience had higher levels of financial literacy. However, it should be noted that this study still focuses on financial literacy in general and has not discussed Islamic financial literacy specifically. This study is also still limited to the aspect of knowledge and does not cover other dimensions.

A study of financial literacy has also been conducted in Indonesia by Lantara and Kartini (2015) at Gajah Mada University. This study took a sample of undergraduate and postgraduate students at Gajah Mada University and found that male students, from the Faculty of Economics and Business, high income, long-standing work experience had higher levels of financial literacy. However, this study still focuses on financial literacy in general and has not discussed Islamic financial literacy specifically. This study is also still limited to the aspect of knowledge and does not cover other dimensions.

Other research in Indonesia which is similar to the study of Lantara and Kartini (2015) but with Islamic financial literacy has been carried out by Setyowati et al. (2018). The unit of analysis in this study has not been specifically for the student group. The dimensional determinants of this study use indicators of financial knowledge dimensions with basic questions on calculation, the basis of usury, gharar, and maysir, and muamalat contracts. Follow-up questions for the determinants of Islamic 
financial literacy in this study relate to Islamic banking, Islamic capital markets, and Islamic nonbanking industries. This research is not in line with the fulfillment of the ideal concept of Indonesian Financial Literacy National Strategy which covers several dimensions in Islamic financial literacy. The independent variable in this study is not a sociodemographic factor but the individual's financial planning.

Research that measures the level of Islamic financial literacy in students has been carried out in other countries. Shakirah et al. (2020) conducted a study of Muslim students in Malaysia and found that students who are accustomed to taking Islamic economics courses can increase their score on Islamic financial literacy. Another study has also been conducted by Douissa (2019) on students in the Middle East. This study uses a multidimensional approach to Islamic financial literacy and finds that female students, who are at the undergraduate level, majoring in the humanities, do not take personal finance courses, have a low achievement index, and have lower family incomes have lower levels of Islamic financial literacy.

From the various studies that have been carried out, it is still rare for Islamic financial literacy studies to be conducted in the context of Muslim students in Indonesia. The author tries to analyze the level of Islamic financial literacy and measure the level of Islamic literacy through a multidimensional approach that is in accordance with the ideal meaning in the revised Indonesian Financial Literacy National Strategy. Therefore, this study seeks to fill the gap from existing research, namely by conducting a study on measuring the level of multidimensional Islamic financial literacy in Muslim students in Indonesia. The study on this topic is important and relevant considering that the 2017 Indonesian Financial Literacy National Strategy revision has perfected the meaning of Islamic financial literacy with fundamental changes because it changes the foundational dimensions of the concept of Islamic financial literacy itself. The urgency of researching students as a unit of study analysis is because students are a priority community group based on the Indonesian Financial Literacy National Strategy to have high financial literacy in Indonesia.

From the various existing studies, it is still rare for Islamic financial literacy studies to be carried out in the context of Muslim students in Indonesia. The author tries to analyze the level of Islamic financial literacy and measure the level of Islamic literacy through a multidimensional approach that is in accordance with the ideal meaning in the revised Indonesian Financial Literacy National Strategy. Therefore, this study seeks to fill the gap from existing research, namely by conducting a study on measuring the level of multidimensional Islamic financial literacy in Muslim students in Indonesia. The study on this topic is important and relevant considering that the 2017 Indonesian Financial Literacy National Strategy revision has perfected the meaning of Islamic financial literacy with fundamental changes because it changes the foundational dimensions of the concept of Islamic financial literacy itself. The urgency of researching students as a unit of study analysis is because students are a priority community group based on the Indonesian Financial Literacy National Strategy to have high financial literacy in Indonesia.

\section{Objective}

This research has the objectives to:

1. Measuring the level of multidimensional Islamic financial literacy of Muslim students at the University of Indonesia.

2. Analyzing the determinants of multidimensional Islamic financial literacy in Muslim students at the University of Indonesia. 


\section{LITERATURE REVIEW}

\section{Background Theory}

Islamic finance is an important part of Islamic economy which deals with the financial aspects of Islamic economy. Islamic finance is based on the principle that money is not a productive asset commodity. One of the basic principles of Islamic financial activity is that money is neither a productive asset nor a commodity. The advantage resulting from this practice is the loss of injustice due to profits that are not based on risk sharing for a business that does not have certainty in profits (Setiwati et al., 2018).

The basic concept can be developed and has implications for various Islamic finance activities. Khaled (2011) reveals that the principles of Islamic finance are based on Islamic law as follows: prohibition of interest; risk sharing; money as potential capital; prohibition of speculative actions; contractual understanding; Sharia-compliant activities; prohibition of short selling. Laldin and Furqani (2013) reveal that there are three main objectives (maqashid) in Islamic finance, namely facilitating the circulation or circulation of assets in society, supporting fair and transparent financial practices, and increasing social and economic justice through services to fulfill financial needs for mankind.

Despite the relatively established concept of Islamic finance, the study of Islamic financial literacy is considered as a relatively new and underdeveloped concept in Islamic finance. Islamic financial literacy is closely related to studies developed in contemporary research on conventional financial literacy. Generally speaking, in the absence of well-established definition of Islamic financial literacy defined by Islamic authorities, it appears that studies generally linked Islamic financial literacy with knowledge related to Islamic finance. However, more recent studies and practices suggest that Islamic financial literacy should be understood as a wider and multidimensional concept involving beyond knowledge aspect. As such, Islamic financial literacy could be conceptually defined as a person's ability to use financial knowledge, skills, and attitudes in managing financial resources according to Islamic teachings (Rahim et al., 2016).

The idea of multidimensional Islamic financial literacy is based on the concept development of the interpretation of the concept of financial literacy, which is only based on the knowledge, skills, beliefs of the concept of financial literacy. This development is in line with research conducted by the OECD (2013) which reviewed that financial literacy is based on 3 dimensions, namely knowledge, attitudes and behavior. Financial knowledge can be defined as an understanding of concepts related to finance and financial skills can be defined as the ability to be able to apply this knowledge to specific financial plans or actions. This dimension reflects technically the individual's mastery in using the ability to calculate in calculating interest, inflation, and risk diversification (Sekita, 2011) as well as planning to optimize financial transactions (Lusardi and Mitchell, 2014). Then, financial attitude is a dimension that shows judgment, the tendency to respond positively or negatively related to money and financial problems (Chaulagain, 2015). Then, financial behavior is a measurement of routine actions in financial management and planning such as activities to record daily finances or timely bill payments. Muslim students should only use financial services that meet the requirements (Chaulagain, 2015).

\section{Previous Studies and Hypotheses Development}

Studies on Islamic financial literacy has been carried out in various Islamic countries, including Jordan, Turkey, United Arab Emirates, and Malaysia (see, among others, Rahim et al., 2016; Er and Mutlu 2017; Douissa 2019; Daradkah et al., 2020; Shakirah et al., 2020). Most of these studies found that the factors that influence Islamic financial literacy are gender, educational background, and work experience which have a significant effect on Islamic financial literacy. 
A study on Islamic financial literacy was carried out in Jordan to review financial literacy in Islamic banking services in Jordan (Daradkah et al., 2020). This study aimed to examine the demographic variables: (gender, age, monthly income, place of residence, education level, and occupation) with ordered logistic regression. This study was conducted by distributing questionnaires with a sample of 385 individuals in Jordan. The study found that $19.5 \%$ of people had a low level of Islamic financial literacy, $45.2 \%$ were in the middle level and $35.3 \%$ had a high level of Islamic financial literacy. The study shows that education level, area of residence, and field of study on Islamic financial literacy level have a significant relationship to Islamic financial literacy. This study uses a questionnaire developed by Rahim et al. (2016).

The research of Rahim et al. (2016) is one of the initiators of the development of measuring the level of Islamic financial literacy. This research was conducted by distributing questionnaires that were filled out independently using a stratified sampling method with 200 respondents from Universiti Utara Malaysia students. Measurement Questionnaire was developed by researchers with unidimensional variables. This study aims to analyze the relationship of financial literacy with 3 factors, namely despair, religiosity, and financial satisfaction. This study aims to develop a valid and reliable questionnaire in Islamic financial literacy.

In a subsequent study, Er and Mutlu (2017) conducted a study on Islamic financial literacy in Turkey by developing a survey of the Islamic financial literacy index through a modification of the financial literacy survey made by Atkinson and Messy (2012) through a survey conducted by the OECD. This research survey has 25 questions with four parts, namely demographics, financial literacy knowledge, financial literacy attitudes, and financial literacy behavior. This study was conducted with 388 respondents in Trabzon. An important issue in the development of this survey is the change in question components such as interest differences and profit sharing. The results of the study findings state that the Islamic financial literacy index has an average score of $58 \%$.

Albaity \& Rahman (2019) in their study to examine the intention to use Islamic banks found that the level of Islamic financial literacy had a significant effect on literacy in the use of Islamic banks. This study uses a judgmental sampling technique that is distributed to working individuals who do not have accounts at Islamic banks. This study obtained 350 respondents who were distributed to the people of the United Arab Emirates. This study found that gender, income level, work experience had a significant effect on financial literacy.

Studies with Islamic financial literacy approach through multidimensional concepts at the student level have been carried out in the United Arab Emirates. A study by Douissa (2019) was conducted with multidimensional Islamic financial literacy but the additional component that includes Islamic financial literacy is only limited to the financial knowledge dimension. The additional component is financial knowledge related to sukuk and investment. This study uses binary logistic regression. The independent variables of this study used age, nationality, education level in students, majors, finance courses, account ownership, father's education, mother's education, and family income. The findings in this study indicate that students from social and humanities, do not take financial courses, score academic achievement index scores, and low family income tend to have low literacy levels.

A similar study was conducted by Shakirah et al., (2020) which tried to add components in the various dimensions of Islamic financial literacy that were not carried out in Douissa (2019) research. The addition of this variable is based on the construction of financial literacy based on the tawhidic-based concept of financial literacy. This study adds a more detailed variable of academic competence with proficiency in English computer literacy, muamalat exposure (participation in education or training programs related to Islamic economics). This study also includes individual characteristic variables such as gender, area of origin (urban, rural), father's education, mother's education, and household income. The research shows that students who take courses or programs of Islamic economics education have better Islamic financial literacy scores. Educational background also has a significant 
impact on financial literacy outcomes. Based on the results of the interviews, it was found that the interaction and social environment of students played an important role in improving their financial literacy.

Regarding the study of Islamic financial literacy in Indonesia, Indonesia as a country with a majority Muslim population developed a national-scale survey to measure Islamic financial literacy in Indonesian society. The Financial Services Authority has conducted the third National Financial Literacy and Inclusion Survey covering 12,773 respondents in 34 provinces and 67 cities/districts. The data collection method was carried out by means of direct interviews with questionnaires adapted from the Financial Capability Survey (2013) and the Global Financial Inclusion Index (2014) organized by the World Bank and the 2015 OECD/INFE Toolkit for measuring financial literacy and financial inclusion carried out by the Organization for Economic Co-operation and Development (OECD). Sharia Aspect Analysis has been developed in 2017 as a forming indicator in the Sharia Financial Literacy Index in Indonesian Financial Literacy National Strategy.

Research on financial literacy in the context of students in Indonesia has been carried out by Lantara and Kartini (2015). This study used 348 respondent data collected from 800 questionnaires distributed to students at Gajah Mada University. This study uses probit and tobit regression tests. The study analyzed the variables by dividing the questionnaire design as follows, sociodemographic background: gender; age; marital status; level of education; income; work experience with the dependent variable of financial literacy which contains questions on knowledge of personal finance, loans and savings, insurance, and investment. The results of this study indicate that male students; majoring in business and economics; higher income; longer work experience tend to have higher levels of financial literacy. The study has not specifically discussed Islamic financial literacy.

Based on the literature reference, it can be concluded that gender, study background, income level, involvement in financial activities (work experience) are suspected to be significant in influencing the level of Islamic financial literacy in students. The next section will explain the influence of the determinants of multidimensional Islamic financial literacy on Muslim students. This explanation is intended to build hypotheses that are relevant in the study.

Women show a lower level of financial literacy than men (Lusardi and Mitchell, 2014). Hsu (2011) explains that the rationalization of this finding is in line with the condition that there is specialization in household affairs which makes married women have an urge to master financial knowledge only when they are at the end of their life or when entering retirement. Edwards et al. (2007) concluded that parents maintain different expectations for boys and girls because parents have higher expectations regarding employment and savings for their sons so that parents focus more on financial education for their men. Lantara and Kartini (2015) through their study of Gajah Mada University students in Indonesia found that gender had a significant relationship to the level of Islamic financial literacy. Thus, the following hypothesis is developed in the study.

\section{H1: Male Students tend to have a higher level of Islamic financial literacy than female students}

Lusardi and Mithcell (2011) in their study show that individuals who are in the age range of 25 and 65 tend to get 5\% higher scores than individuals who are under the age of 25 and over 65 years. This finding is in line with the findings of Lantara and Kartini (2015) in their research with the unit of analysis of Indonesian students who found that there was a significant relationship between age and financial literacy level. Thus, the following hypothesis is developed in the study.

\section{H2: Older stdents tend to have higher levels of Islamic financial literacy than younger students}

Marital status is thought to have a relationship with a person's level of financial literacy. Brown \& Graf (2013) revealed that someone who is single tends to have a lower level of financial literacy. Long-term relationship welfare in marriage requires a good literacy level because with low literacy 
levels they are at risk of making long-term decisions that can result in debt that endangers marital welfare (Dew, 2008). Thus, the following hypothesis is developed in the study.

H3: Married students tend to have higher levels of Islamic financial literacy than unmarried students

Family background is thought to significantly influence how financial literacy in children is formed. Parents who have a good education will provide financial direction or teaching specifically in formal or informal education (Calamanto, 2010). Calamanto (2010) found that $87 \%$ of students learned money management from their parents in their teens by studying their parents' money management actions. Furthermore, Shim et al. (2010) found that the role of parents has a more significant role in the level of financial literacy than financial education in schools. A study conducted by Lyons et al. (2006) on students and college students who participated in financial education workshops showed that 77 percent of students said that they obtained financial knowledge from their parents. Financial attitudes and behavior are also very dependent on how family members are accustomed to financial transaction interactions such as business, investment, or work professionalism (Clark, 2009). Thus, the following hypotheses are developed in the study.

H4: Students whose mothers have a higher education level tend to have a higher level of Islamic financial literacy than students whose mothers have a lower educational level

H5: Students whose fathers have a high level of education tend to have a higher level of Islamic financial literacy than students whose fathers have a low level of education

The study of Atkinson and Messy (2012) found that the level of education is related to the level of literacy. The increase in financial education was shown to be associated with an increase in the level of individual literacy in the 12 countries that became the unit of analysis of the study. The findings in Lusardi and Mitchel (2011) state that someone with a low level of education tends to choose the option of not knowing and answering incorrectly on a questionnaire about financial literacy. Douissa (2019) also found similar findings with the significance of a person's level of education at the student level. Thus, this study develops the following hypothesis.

H6: Students with higher levels/years of education tend to have higher levels of Islamic financial literacy than students with lower levels/years of education

The research conducted by Peng et al. (2007) shows that students who take personal finance courses are proven to increase their knowledge of investment knowledge and have a positive tendency to save attitudes. Students who were in the fields of study related to economics, business, accounting, and finance were found to have higher literacy levels than students who were outside the fields of study (Chen and Volpe, 1998; Lantara and Kartini, 2015; Shakirah et al., 2020). Thus, this study develops the following hypothesis.

H7: Students from the Faculty of Economics and Business tend to have a higher level of Islamic financial literacy than students who are not from the Faculty of Economics and Business.

Islamic Economics and Islamic Business Program Study students follow learning materials that are considered to be able to improve their Islamic financial literacy skills. The curriculum with courses followed by Islamic Economics and Islamic Business Study Program students at the University of Indonesia is considered to support Islamic financial literacy with courses. These courses include Fiqh Muamalat, Fiqh Riba and Gharar, as well as Introduction to Islamic Finance and Banking. The courses in the study program are expected to significantly affect the increase in Islamic financial literacy (FEB UI, 2017). Thus, this study develops the following hypothesis.

H8: Students from Islamic Economics or Islamic Business majors tend to have a higher level of Islamic financial literacy than non-Islamic Economics students

The level of a person's wealth has a positive effect on the level of financial literacy (Monticone, 2010). Students from high-income families have a much higher level of knowledge than students from low-income families (Johnson \& Sherraden, 2007). A study by Lantara and Kartini (2015) on 
Indonesian students proved that the level of student income was positively related to the level of literacy. The monthly income considered in this analysis is adjusted to the condition that students in Indonesia have income that can be obtained from part-time work, business, and pocket money provided by parents. Thus, this study develops the following hypothesis.

H9: Students with higher income levels tend to have higher levels of Islamic financial literacy than students with lower income levels.

A study conducted by Mandell and Hanson (2009) revealed that American students who are experienced in dealing with problems related to financial management are able to increase the average score of the level of financial literacy. Douissa (2019) in his research proves that someone who uses a credit card and has a bank account is proven to be positively correlated with literacy levels. The study proves that students who have bank accounts have better financial skills. The author tries to make a separate indicator approach which the author adapts from the explanation of Laldin and Furqani (2013) regarding the means and objectives of Islamic finance from the Maqashid Syariah framework. Thus, this study develops the following hypothesis.

H10: Students who have Islamic bank accounts tend to have higher levels of Islamic financial literacy than students who only have conventional bank accounts.

\section{METHOD}

\section{Data}

This study uses primary data obtained through questionnaires distributed to Muslim students online. This questionnaire is a self-assessment that is intended for a unit population analysis of students at the level or below a bachelor's degree with an estimated 32,014 students at the University of Indonesia using cluster random sampling technique and the Slovin method in determining the number of samples. There are 3 reasons why the University of Indonesia is the unit of analysis in the study, namely the University of Indonesia which is a reference for other universities in Indonesia, University of Indonesia students are representative to represent the characteristics of Indonesian youth and students based on the proportion of the National Population Census (BPS, 2021), and the University of Indonesia presents diversity of varied study backgrounds with a total of 14 faculties spread into three clumps.

This research was subsequently conducted by collecting primary data distributed through online-based questionnaires through the Google Form platform. The study managed to collect data from 439 respondents, which is above the minimum number of research samples based on the Slovin formula. Data processing was carried out using the SPSS application which was needed for the analysis of sociodemographic relationships at the individual Islamic financial literacy level. The questionnaire contains screening questions so that respondents meet the criteria for being Indonesian citizens, Muslim, and undergraduate students and below which are adjusted to the unit of analysis.

The survey was conducted by using the Cluster Random Sampling technique. This sampling technique was chosen to adjust to research needs where the results obtained from each sample are relatively heterogeneous and between clusters are relatively similar (Sugiono, 2016). This questionnaire is a self-assessment that is intended for students at the level or below undergraduate students at the University of Indonesia. Data was collected by distributing questionnaires to students from various faculties at the university. The ideal proportion of sample returns is adjusted to the distribution of undergraduate students within the faculty. The author uses the Slovin method to be the author's reference in determining the number of samples needed for a relatively large data population (Sugiono, 2016). 


\section{Methods and Model Development}

The dependent variable in this study is the level/index of multidimensional Islamic financial literacy. The level of Islamic financial literacy will be calculated using a formula adapted from Douissa (2019). The formula is as follows:

$$
\begin{gathered}
\text { Multidimensional } \\
\text { Financial Literacy Index }
\end{gathered}=\frac{\text { Fin. Know. score }+ \text { Fin. Beh. score + Fin. Att. score }}{\text { Overall Maximum Xcore }} \times 100
$$

It is notable that the multidimensional Islamic financial literacy includes three dimensions, namely financial knowledge (10 question components), behavior (10 question components), attitude (5 question components). This study uses a measurement of multidimensional Islamic financial literacy modified from the measurement of the Islamic financial literacy index in previous studies (Atkinson and Messy (2012); Antara et al., 2016; Douissa, 2019; Laldin and Furqani, 2013; Shakirah et al., 2020). The measurement used could be summarizes as follow. The questionnaire to measure the level of multidimensional Islamic financial literacy is summarized in Table 1 (the questionnaire items are summarized in Appendix 1).

The items were subsequently tested for their reliability and validity. Based on the tests, all statement items in financial attitudes and financial behavior can be declared valid with the reference based on the Pearson Product Moment approach. Sugiono (2016) which states that the criteria that must be met so that the statement from the questionnaire is declared valid is if $r>0.30$. Furthermore, the attitude variable can be stated to have moderate reliability with Cronbach's alpha value of 0.575 . The reliability results have been treated on variables by eliminating one of the indicators, namely Attitude_1 which has a tendency to be inconsistent or negate the results of the indicators. Thus, in the subsequent review of literacy levels, this study decided to remove these indicators by retaining four indicators in financial attitudes from the five existing indicators. Behavioral variables are declared to have high reliability with a value of 0.759 (the complete results can be seen in Appendix 2).

The independent variables in this study include students' sociodemographic factors that are in accordance with the development of hypothesis testing. The independent variables in this study include students' sociodemographic factors. The variables were gender, marital status, age, father's education level, mother's education level, students, majors, income, and bank account ownership. These variables were adapted and based on the literature from previous similar studies and adapted to the conditions of Muslim students in Indonesia.

Next, this study employs the Ordinal Logistic Regression method to see the significance of sociodemographic determinants on multidimensional Islamic financial literacy in students. Inferential analysis was conducted to provide an explanation of the significance of the effect of the independent variables used to explain the level of Islamic financial literacy. The grouping of dependent variables for ordinal analysis follows the Financial Services Authority categorization, the dependent variable on the results formulated into three categories, namely more than $0-25 \%$ in the very low category, 25 $50 \%$ in the low category, $50-75 \%$ in the moderate category, and above $75 \%$ is high (OJK, 2013). This study found one outlier respondent who was in the "very low" literacy level category in the analysis of the results so that the respondent was grouped in the "low" category. In addition, to sharpen the results, several variables were tested for mean differences using relevant methods such as cross tabulation and non-parametric tests using the Mann-Whitney method (Neuhäuser, 2011).

\section{RESULTS AND DISCUSSION}

\section{Results}

Table 1 shows the percentage distribution of the respondents' multidimensional Islamic financial literacy level. The largest percentage of respondents' multidimensional Islamic financial literacy is at 
the moderate level with 220 respondents $(50.1 \%)$. Furthermore, the high literacy rate is in second place with 191 respondents $(43.5 \%)$. The smallest percentage is in the low literacy level with a total of 61 respondents $(6.4 \%)$. The findings of the distribution of this study are similar to the distribution characteristics of Daradkah et al. (2020). The study found that $19.5 \%$ of people had a low level of Islamic financial literacy, $45.2 \%$ were in the middle level and $35.3 \%$ had a high level of Islamic financial literacy.

Table 1 Distribution of multidimensional sharia literacy level

\begin{tabular}{cccc}
\hline & & Frequency & Percentage \\
\hline Valid & Low & 28 & $6.4 \%$ \\
& Moderate & 220 & $50.1 \%$ \\
& High & 191 & $43.5 \%$ \\
\cline { 2 - 3 } & Total & 439 & 100.0 \\
\hline
\end{tabular}

Table 2 Summary of regression test results

\begin{tabular}{|c|c|c|c|}
\hline Variable & Group & $\begin{array}{l}\text { Estimated } \\
\text { coefficient }\end{array}$ & Significance \\
\hline Age & & 0.103 & 0.380 \\
\hline \multirow{2}{*}{ Gender } & Male & 0.207 & 0.325 \\
\hline & Female & $0 \mathrm{a}$ & \\
\hline \multirow{2}{*}{ Marital Status } & Married & 1.360 & 0.240 \\
\hline & Single & $0 \mathrm{a}$ & 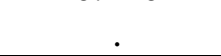 \\
\hline \multirow{3}{*}{$\begin{array}{l}\text { Mother's } \\
\text { Education Level }\end{array}$} & Undergraduate-Postgraduate & -0.308 & 0.477 \\
\hline & High School & -.0 .116 & 0.781 \\
\hline & Under High School & $0 \mathrm{a}$ & \\
\hline \multirow{3}{*}{$\begin{array}{l}\text { Father's } \\
\text { Education Level }\end{array}$} & Undergraduate-Postgraduate & -0.433 & 0.370 \\
\hline & High School & -0.166 & 0.724 \\
\hline & Under High School & $0 \mathrm{a}$ & \\
\hline \multirow{5}{*}{$\begin{array}{l}\text { Level of } \\
\text { education }\end{array}$} & Over $4^{\text {th }}$ year & 2.152 & 0.081 \\
\hline & $4^{\text {th }}$ year & -0.463 & 0.230 \\
\hline & $3^{\text {rd }}$ Year & 0.437 & 0.236 \\
\hline & $2^{\text {nd }}$ & 0.115 & 0.672 \\
\hline & $1^{\text {st }}$ year & $0 \mathrm{a}$ & \\
\hline \multirow[t]{2}{*}{ Faculty } & FEB ((Faculty of Economics and Business) & 0.630 & $0.007 * * *$ \\
\hline & Non-FEB & $0 \mathrm{a}$ & \\
\hline \multirow[t]{2}{*}{ Major } & IEIBI (Islamic Economics and Business) & 0.373 & 0.248 \\
\hline & Non-IEIBI & $0 \mathrm{a}$ & . \\
\hline \multirow[t]{6}{*}{ Monthly Income } & (> 5 million) & 0.160 & 0.751 \\
\hline & (4-5 million) & -0.849 & 0.137 \\
\hline & (3-4 million) & 0.294 & 0.594 \\
\hline & (1,75-3 million $)$ & 0.679 & $0.047 * *$ \\
\hline & $(1,25-1,75$ million $)$ & 0.522 & 0.87 \\
\hline & $(<1,25$ million $)$ & $0 \mathrm{a}$ & \\
\hline Savings & Conventional Banks and Islamic Banks & 0.157 & 0.243 \\
\hline \multirow[t]{2}{*}{ Ownership } & Conventional Bank only & -0.785 & $0.012 * *$ \\
\hline & Sharia Bank only & $0 \mathrm{a}$ & \\
\hline
\end{tabular}

Note: $* *$ and $* * *$ show $5 \%$ and $1 \%$ significance level

Table 2 summarizes the results of the regression tests performed. In the ordinal logistic regression test that uses ordinal independent variables, a review of the significance of the variables is assessed from the influence of certain groups of variables on the reference group. The estimated coefficient value

AL-MUZARA'AH Special Issue 2022 
shows the direction or relationship of the independent variable to the dependent variable. The decision in testing this hypothesis is done with a significance level (alpha) of 0.05 .

Based on the results, the independent variables that affect the level of multidimensional Islamic financial literacy are faculty, monthly income, and savings ownership. The conclusion on the faculty variable was declared significant based on the FEB group which had a sig value of 0.007 (below 0.05). Furthermore, the conclusion on the significant monthly income variable is based on the reference value in the group (1.75-3 million) which has a value of 0.047 (below 0.05). In addition, the findings in the study prove that the respondent's bank account ownership in the group that has only conventional banks is significant with a value of 0.012 (below 0.05). The variables of age, marital status, gender, mother's education level, father's education level, education level, and major were not proven to significantly affect the level of multidimensional Islamic financial literacy.

Logistic regression does not require assumptions of normality, heteroscedasticity, and autocorrelation, because the dependent variable contained in logistic regression is a graded ordinal variable, so the residuals do not require the three tests. In this test, the author includes a feasibility test, coefficient of determination, and parallel lines test to show the goodness of the model in explaining the results of Ghozali (2011). In the the overall model fit test after the addition and the iteration process is 736,202 with a chi square value of 68,798 , the value of the $p$ value is 0.000 . These results show significant results because the value is smaller than 0.05 . This value indicates that all independent variables in the model have a significant effect simultaneously on the dependent variable. Then, based on the Goodness of Fit test through the Pearson approach to show the model's suitability test with the data. The Pearson Chi Square value is 694,337 with a value of $0.26(>0.05)$ (See the detailed results in Appendix 3). These results indicate that the model is in accordance with the empirical data, or the mean model is feasible to use. The value of the Pseudo R-Square in the regression results shows the Nagelkerke value of $0.175(17.5 \%)$ in explaining the independent variable in explaining the dependent variable.

\section{Analysis}

\section{Relationship between Islamic financial literacy level and faculty}

Based on the significance test in Table 3 Summary of Regression Test Results, students who are in the Faculty of Economics and Business have a coefficient of 0.630. This can be interpreted those students who are in the Faculty of Economics and Business tend to have a level of Islamic financial literacy 1.87 times greater than students who are not from the Faculty of Economics and Business. This finding is in line with the findings of Chen and Volpe (1998) on American students and Lantara and Kartini (2015) on Indonesian students at Gajah Mada University with a significant effect of business faculty on higher levels of financial literacy. This finding confirms a study conducted by Asarta et al. (2014) that a learning curriculum that includes learning related to finance can improve financial literacy.

\section{Relationship between Islamic financial literacy level and majors}

The results of the hypothesis test described in Table 3 show that majors are not proven to significantly affect the level of Islamic financial literacy. This result is something that is odd when compared to the findings on the faculty hypothesis test as the educational background of respondents which is proven to significantly affect the level of Islamic financial literacy.

\begin{tabular}{lc} 
Table 3 Mann Whitney test in majors on financial literacy \\
\multicolumn{1}{c}{ Variable } & Asymp.Sig. \\
\hline Sharia Financial Knowledge & 0.000 \\
Sharia Financial Attitude & 0.024 \\
Sharia Financial Behavior & 0.509 \\
\hline
\end{tabular}


Table 3 shows the significance of the test based on the Mann-Whiteney Test between IEIBI and NonIEBI majors. The Mann-Whitney test is a non-parametric test to see the difference between the mean values. The estimation results show that financial knowledge has an asymp.sig value of 0.000 $(<0.005)$, which indicates that there is a significant difference in financial knowledge scores between IEIBI and non-IEBI students. The test. The estimation results show that financial knowledge has an asymp.sig value of $0.000(<0.005)$, which indicates that there is a significant difference in financial knowledge scores between IEIBI and non-IEBI students. In other words, there are differences in the literacy level of Islamic finance knowledge in different majors. This is very rational, considering that students majoring in IEIBI have gained basic knowledge about Islamic economics since they were in the second level of lectures. The basic knowledge includes, among others, muamalah fiqh, usury and gharar fiqh, Islamic public finance and Islamic accounting as explained in the academic guidebooks of the Islamic Economics Study Program and Islamic Business Study Program (FEB UI, 2017).

Then, the financial attitude has a value of asymp.sig, $0.240(<0.05)$ indicating a significant difference between students majoring in IEIBI and Non-IEIBI in the aspect of Islamic financial attitudes. The estimation results show that the financial attitude has an asymp.sig value of $0.024(<0.05)$ which indicates a significant difference in the financial attitude score between IEIBI and non-IEIBI students. This finding is very rational if we consider that IEIBI students get attitude formation from a conducive environment with the auspices of the IEIBI Study Program student association, IBEC, which carries universal Islamic values as a reference in organizational activities (IBEC FEB UI, 2021).

While related to financial behavior, the value of asymp.sig. $0.509(>0.05)$ indicates that the financial attitudes of the IEIBI and Non-IEIBI majors do not have a significant difference. These results indicate that there is no difference in the level of Islamic financial literacy in different majors. This happens because a person's financial behavior is not only influenced by attitudes and knowledge. Studies on individual behavior have shown that financial behavior is not always correlated with one's abilities. Chaulagain's study (2015) states that culture, values, experiences, and surrounding situations are the main factors that influence a person's financial behavior.

Then, financial behavior is also very dependent on how family members are accustomed to financial transaction interactions (Clark, 2009). Table 3 shows that the largest percentage of characteristics of bank account ownership by IEIBI students is in conventional bank account ownership only. This finding is in line with the situation that IEIBI students cannot be separated from the behavior of their family or relatives in students' daily lives to use conventional savings accounts in financial activities. Insignificant results of the variables in the majors in multidimensional Islamic financial literacy are thought to be due to the absence of significant differences in the majors on the behavioral dimensions of Islamic finance.

\section{Relationship between Islamic financial literacy level and income}

The income variable significantly affects the level of Islamic financial literacy based on a review of the significance of the influence of the income level at the level of Rp. 1,750.000,00 - Rp. $3,000,000.00$ to the group below Rp. 1,250,000.00 with a coefficient of 0.679 with a value or it can be interpreted that students have income of Rp. 1,750,000.00 - Rp. 3,000,000.00 has the potential to predict an increase in literacy by log odds of 0.679 or 1.971 times more likely to have a higher literacy level than students who have incomes below Rp. 1,250,000.00. In other words, the group of students with an income range of Rp. 1,750.000,00 - Rp. 3,000,000.00 has a higher probability of financial literacy by 1.9 times compared to students with the lowest income range. This finding is in line with the hypothesis rationalization in the study which states that students from high-income families have a much higher level of knowledge than students from low-income families (Johnson \& Sherraden, 2007). This rationalization is in line with the characteristics of respondents where Muslim students at the University of Indonesia generally still get pocket money with financial conditions that are partly borne by the family, not from income earned from work or business. 


\section{Relationship between Islamic financial literacy level and bank account ownership}

The results of the hypothesis test described in Table 3 show that the variable of bank account ownership significantly affects the level of Islamic financial literacy. Based on the significance test, students who are at have only conventional bank accounts and accounts have a coefficient of -0.785 each. This value can be interpreted that students who have only conventional banks have the potential to predict an increase in literacy 0.45 times more likely to have a higher literacy level than students who have only Islamic bank accounts. In other words, someone who only has a conventional bank account tends to have a lower level of Islamic financial literacy compared to other groups of students. This finding is in line with the findings of Douissa (2019) which shows that bank account ownership is significantly related to the level of Islamic financial literacy.

\section{CONCLUSION}

\section{Conclusion}

Although Indonesia is the largest Muslim country in the world, the level of Islamic financial literacy in Indonesia is still very low. The Islamic financial literacy index in Indonesia is at $8.93 \%$, much lower than the conventional financial literacy index which reached $37.72 \%$ in 2019 . Therefore, this study aims to analyze the determinants of Islamic financial literacy in Indonesia amongst university students which is a group prioritized by government policies in improving Islamic financial literacy. To achieve this goal, this study develops a multidimensional Islamic financial literacy instrument that includes aspects of knowledge, attitudes and behavior and measures the multidimensional Islamic financial literacy amongst university students. The study managed to collect primary data from 439 students from University of Indonesia and analyzed them using logistic regression method with Islamic financial literacy scores as the dependent variable and socio-demographic factors as the independent variables.

Based on the results of the analysis described in the previous section, it can be concluded that from a total sample of 439 respondents, the findings in this study indicate that $6.4 \%$ of UI students have a low level of Islamic financial literacy. $50.1 \%$ of students have a moderate level of Islamic financial literacy. Furthermore, $43.5 \%$ of students have a high level of Islamic financial literacy. Based on the estimation results, the tendency to have a higher level of Islamic financial literacy is found in respondents who are in the Faculty of Economics and Business, have a higher income level, and have a Sharia bank account. The IEIBI major has been shown to significantly influence the level of Islamic financial literacy on the dimensions of financial attitudes and financial knowledge. Meanwhile, the variables of gender, marital status, age, mother's education level, father's education level, and education level did not significantly affect the level of Islamic financial literacy in this study. Although this study found that there was no significant difference in multidimensional Islamic financial literacy scores between students with Islamic economics and business (IEIBI) and non-IEIBI majors, further analysis showed that there were differences in aspects of knowledge and attitudes towards Islamic finance which is two of the three components of the multidimensional Islamic financial literacy index.

\section{Recommendations and Limitations of Study}

Based on the study's findings, the findings are expected to be able to provide information to the government and stakeholders related to the development of students' Islamic financial literacy. Then, the results of the analysis on the determinants of Islamic financial literacy are expected to provide insight into the factors that influence the level of student Islamic financial literacy so that the Islamic financial literacy strategy can be aimed at groups of students who have moderate and low financial literacy. Mastery over issues related to usury and relatively small profit sharing can be a reference for developing campaigns in education related to Islamic financial literacy. Furthermore, the findings in the study are also expected to enrich studies related to Islamic financial literacy in Indonesia, 
especially among Muslim students. In addition, these findings are also expected to be useful insights as material for reflection for Muslim students in addressing financial literacy to improve welfare.

Despite the results above, it is realized this study has several limitations. In terms of sample, the study has an uneven distribution of the proportion of respondents with the majority of respondents coming from the Faculty of Economics and Business with 195 respondents (44.4\%). Further research can conduct a sampling process with more proportional respondents regarding the number of respondents who are able to present the characteristics of diverse study backgrounds. Respondents in this study are also limited to the unit of analysis for University of Indonesia students at the undergraduate level or below who have not been able to present representative results to represent postgraduate students. Thus, further research can be directed at expanding the scope of the study analysis unit to show more representative results in describing the level of multidimensional Islamic financial literacy.

\section{Appendix 1 Questionnaire Items}

\begin{tabular}{|c|c|c|}
\hline Dimensions & Question Topics & Sources \\
\hline \multirow{10}{*}{$\begin{array}{l}\text { Sharia } \\
\text { Finance } \\
\text { Knowledge } \\
\text { (10 questions) }\end{array}$} & - Money calculation & Atkinson and Messy (2012) \\
\hline & - Profit sharing calculation & Laldin and Furqani (2013) \\
\hline & - Zakat Maal misab & Laldin and Furqani (2013) \\
\hline & - Zakat Fitrah & Laldin and Furqani (2013) \\
\hline & - Level of risk in investment & Douissa (2019) \\
\hline & - Shares and Sukuk & Douissa (2019) \\
\hline & - Calculation of product purchase costs & Atkinson and Messy (2012) \\
\hline & - Musharakah & Antara et al. (2016) \\
\hline & - Gharar & Antara et al. (2016) \\
\hline & - Qard & Antara et al. (2016) \\
\hline \multirow{5}{*}{$\begin{array}{l}\text { Sharia } \\
\text { Financial } \\
\text { Attitudes } \\
(5 \text { questions)) }\end{array}$} & - Long-term use of assets & Atkinson and Messy (2012) \\
\hline & - Belief in the benefits of zakat & Laldin and Furqani (2013) \\
\hline & - Avoidance of usury practices & Shakirah et al. (2020) \\
\hline & - Worship Awareness & Laldin and Furqani (2013) \\
\hline & - Faith avoids Gharar & Laldin and Furqani (2013) \\
\hline \multirow{10}{*}{$\begin{array}{l}\text { Sharia } \\
\text { Financial } \\
\text { Behavior } \\
\text { (10 questions) }\end{array}$} & - Consideration of property allocation & Atkinson and Messy (2012) \\
\hline & - Billing compliance & Atkinson and Messy (2012) \\
\hline & - Long term financial planning & Atkinson and Messy (2012) \\
\hline & $\begin{array}{l}\text { - Behavior to avoid extravagant lifestyle and } \\
\text { excessive lifestyle. }\end{array}$ & Atkinson and Messy (2012) \\
\hline & - Avoidance of usury practices & Shakirah et al. (2020) \\
\hline & - I fulfill financial transaction obligations & Rahim et al. (2016) \\
\hline & $\begin{array}{l}\text { Provision of personal assets for infaq, sadaqah, } \\
\text { grants, and qard }\end{array}$ & Laldin and Furqani (2013) \\
\hline & - Avoidance of the attitude of israf, bukhl, ihtikar & Laldin and Furqani (2013) \\
\hline & - Asking Allah for help in difficult times & Shakirah et al. (2020) \\
\hline & - Behavior to donate as a sign of gratitude & Shakirah et al. (2020) \\
\hline
\end{tabular}


Appendix 2 Results of Validity Tests

\begin{tabular}{cccc}
\hline Variable & Item & $\begin{array}{c}\text { Nilai Sig. } \\
\text { (2-tailed) }\end{array}$ & $\begin{array}{c}\text { Pearson } \\
\text { Correlation }\end{array}$ \\
\hline \multirow{5}{*}{ Attitude } & Attitude_1 & 0.000 & 0.421 \\
& Attitude 2 & 0.000 & 0.538 \\
& Attitude 3 & 0.000 & 0.693 \\
& Attitude_4 & 0.000 & 0.621 \\
& Attitude_5 & 0.000 & 0.595 \\
\hline \multirow{5}{*}{ Behavior } & Behavior_1 & 0.000 & 0.475 \\
& Behavior_2 & 0.000 & 0.475 \\
& Behavior_3 & 0.000 & 0.529 \\
& Behavior_4 & 0.000 & 0.579 \\
& Behavior_5 & 0.000 & 0.562 \\
& Behavior_6 & 0.000 & 0.630 \\
& Behavior_7 & 0.000 & 0.585 \\
& Behavior_8 & 0.000 & 0.631 \\
& Behavior_9 & 0.000 & 0.582 \\
\hline
\end{tabular}

\begin{tabular}{lllll}
\multicolumn{5}{c}{ Appendix 3 Model Fit Test } \\
\hline Model Fitting Information \\
\hline Model & $\begin{array}{c}-2 \text { Log } \\
\text { Likelihood }\end{array}$ & Chi-Square & df & Sig. \\
\hline Intercept Only & 690.668 & & & \\
Final & 621.870 & 68.798 & 20 & .000 \\
\hline
\end{tabular}

\begin{tabular}{lrrr}
\multicolumn{4}{c}{ Goodness of Fit } \\
\hline & Chi-Square & df & \multicolumn{1}{c}{ Sig. } \\
\hline Pearson & 694.337 & 650 & .111 \\
Deviance & 558.761 & 650 & .996 \\
\hline
\end{tabular}

\section{REFERENCES}

Albaity, M., \& Rahman, M. (2019). The intention to use Islamic banking: an exploratory study to measure Islamic financial literacy. International Journal of Emerging Markets, 14(5), 9881012.

Antara, P., Musa, R. \& Hassan, F. (2016). Bridging Islamic financial literacy and halal literacy: The way forward in halal ecosystem. Procedia Economics and Finance, 196-202.

Asarta, C. J., Hill, A. T. \& Meszaros, B. T. (2014). The features and effectiveness of the keys to financial success curriculum. International Review of Economics Education, 16, 39-50.

Atkinson, A. \& Messy, F. (2012). Measuring financial literacy: Results of the OECD/International Network on Financial Education (INFE) Pilot Study. OECD Working Papers on FInance, Insurance and Private.

Beal, D. \& Delpachitra, S. (2003). Financial literacy among Australian university students. Economic Papers: A Journal of Applied Economics and Policy, 22(1), 65-78.

Beverly, S. G. \& Burkhalter, E. (2005). Improving financial literacy and practices of youths. Children and Schools, 27, 121-124. 
[BPS] Badan Pusat Statistik. (2021). Hasil Sensus Penduduk 2020 [online]. Retrieved 2021 Jun 6 from https://www.bps.go.id/pressrelease/2021/01/21/1854/hasil-sensus-penduduk-2020.html.

Brown, M. \& Graf, R. (2013). Financial literacy and retirement planning in Switzerland. Numeracy, 6(2), 2-23.

Calamanto. (2010). Learning Financial Literacy in the Family. (Master Thesis, San Jose State University, San Jose, United States).

Chaulagain. (2015). Contribution of financial literacy to behavior. Journal of Economics and Behavioral Studies, 7(6), 67-71.

Chen H. \& Volpe, R. P. (1998). An analysis of personal financial literacy among college students. Financial Service Review, 7, 107.

Clark. (2009). Why Fathers Matter to their Children's Literacy. London (UK), Nacional Literacy Trust.

Daradkah, D., Aldaher, A. A. \& Shinaq, H. R. (2020). Islamic financial literacy: Evidence from Jordan. Journal of International Finance Studies, 131-145.

Dew, J. (2008). Debt change and marital satisfaction change in recently married couples. Family Relations, 57(1), 60-71.

Douissa, I. B. (2019). Factors affecting college students' multidimensional financial literacy in the Middle East. International Review of Economics Education, 35.

Edwards, R., Allen, M. W. \& Hayhoe, C. R. (2007). Financial attitudes and family communication about students' finances: The role of sex differences. Communication Reports, 20(2), 90-100.

Er, B., \& Mutlu, M. (2017). Financial inclusion and Islamic finance: A survey of Islamic financial literacy index. International Journal of Islamic Economics and Finance Studies, 3(2), 33-54.

[FEB UI] Fakultas Ekonomi dan Bisnis Universitas Indonesia. (2017). Pedoman Akademik Program Sarjana Edisi 2017/2018. Depok (ID), FEB UI.

Ghozali, I. (2011). Aplikasi Analisis Multivariate dengan Program SPSS. Semarang (ID), Badan Penerbit Universitas Diponegoro.

Hsu, J. W. (2016). Aging and strategic learning: The impact of spousal incentives on financial literacy. Journal of Human Resources, 51(4), 1036-1067.

Huston, S. J. (2010). Measuring financial literacy. Journal of Consumer Affairs, 44(2), 296-316.

[IBEC FEB UI] Islamic Business and Economics Community. (2021). Visi \& Misi IBEC FEB UI [online]. Retrieved 2021 Jun 6 from https://www.ibec-febui.com/visi-misi/.

Johnson, E. \& Sherraden, M. S. (2007). From financial literacy to financial capability smong youth. Journal of Sociology \& Social Welfare, 34, 119.

Khaled, M. (2011, November). Building a successful business model for Islamic microfinance. In Global Microcredit Summit Commissioned Workshop Paper, 14-15.

Laldin, M. A. \& Furqani, H. (2013). Developing Islamic finance in the framework of maqasid alshari'ah. International Journal of Islamic and Middle Eastern Finance and Management, 278289.

Lantara, I. W. \& Kartini, N. K. (2015). Financial literacy among university student: Empirical evidence from Indonesia. Journal of Indonesia Economy and Business, 30(3), 257-256.

Letkiewicz, J. C. \& Fox, J. J. (2014). Conscientiousness, financial literacy, and asset accumulation of young adults. Journal of Consumer Affairs, 48(2), 274-300.

Lusardi, A. \& Mitchell, O. (2011). Financial Literacy and Planning: Implications for Retirement Wellbeing. Oxford (UK), Oxford University Press.

Lusardi, A. \& Mitchell, O. (2014). The economic importance of financial literacy: Theory and evidence. Journal of Economic Literature, 52(1), 5-44.

Lyons, A. C., Palmer, L., Jayaratne, K. S., \& Scherpf, E. (2006). Are we making the grade? A national overview of financial education and program evaluation. Journal of Consumer Affairs, 40(2), 208-235.

Mandell, L. \& Hanson, K. O. (2009, January). The impact of financial education in high school and college on financial literacy and subsequent financial decision making. In American Economic Association Meetings, San Francisco, CA (Vol. 51, pp. 1-38).

Monticone, C. (2010). How much does wealth matter. The Journal of Consumer Affairs, 44(2), 403-

AL-MUZARA'AH Special Issue 2022 
423.

Neuhäuser. (2011). Wilcoxon-Mann-Whitney Test. International Encyclopedia of Statistical Science. New York (US), Springer.

OECD [Organisation for Economic Co-operation and Development]. (2013). PISA 2012 Financial Literacy Framework [online]. Retrieved 2021 Jun 6 from https://www.oecd.org/daf/fin/financia 1-education/ PISA2012FrameworkLiteracy.pdf.

[OJK] Otoritas Jasa Keuangan. (2013). Strategi Nasional Literasi Keuangan Indonesia (SNLKI). Jakarta (ID), OJK.

[OJK] Otoritas Jasa Keuangan. (2017). Strategi Nasional Literasi Keuangan Indonesia (Revisit 2017). Jakarta (ID), OJK.

[OJK] Otoritas Jasa Keuangan. (2019). Survei Nasional Literasi dan Inklusi Keuangan [online]. Retrieved 2021 Jun 6 from https://www.ojk.go.id/id/berita-dan-kegiatan/publikasi/Documnets/ Pages/Survei-Nasional-Literasi-dan-Inklusi-Keuangan-2019/BOOKLET\%20Survei\%20Nasio nal\%20Literasi\%20dan\%20Inklusi\%20Keuangan\%202019.pdf.

Peng, T., Bartholomae, M., Cravener, S., \& Fox, G. (2007). The impact of personal finance education delivered in high school and college courses. Journal of Family Indomes Issues, 28, 271.

Rahim, S., Rashid, R., \& Hamed, A. B. (2016). Islamic financial literacy and its determinants among university student: An exploratory factor analysis. International Journal of Economics and Financial Issue, 6, 32-35.

Sekita, S. (2011). Financial literacy and retirement planning in Japan. Journal of Pension Economics \& Finance, 10(4), 637-656.

Setiwati, R., Nidar, S. R., Anwar, M., \& Masyita, D. (2018). Islamic financial literacy: construct process and validity. Academy of Strategic Management Journal, 17(4), 1-12.

Setyowati, A., Harmadi, H., \& Sunarjanto, S. (2018). Islamic financial literacy and personal financial planning: A socio-demographic study. Jurnal Keuangan dan Perbankan, 22(1), 63-72.

Shakirah, A., Shafik \& Ahmad, W. M. (2020). Financial literacy among Malaysian Muslim undergraduates. Journal of Islamic Accounting and Business Research, 11, 1515-1529.

Shim, S., Barber, B. L., Card, N. A., Xiao, J. J., \& Serido, J. (2010). Financial socialization of firstyear college students: The roles of parents, work and education. Journal of youth and adolescence, 39(12), 1457-1470.

Sugiono, S. (2016). Metode Penelitian Kuantitatif, Kualitatif, dan R \& D. Bandung (ID), Alfabeta.

Williams, T. (2007). Empowement of whom and for what? Financial literacy education and the new regulation of consumer financial serivices. Law and Policy, 29(2), 226-256. 